\title{
Tēnā koe Hēmi Kāwana: A Ngāti Maniapoto Half-Caste from Kihikihi Greets Mr James Cowan ${ }^{1}$
}

\author{
PAUL MEREDITH
}

\begin{abstract}
This article explores and evaluates, from an iwi/Māori perspective, the presence of James Cowan in the early twentieth-century collection and recording of Ngāti Maniapoto's tribal knowledge, past narratives and Pākehā encounter history on the "frontier" border around the Pūniu River. This includes the extent to which Cowan empathised, identified with, and participated in the lives of the Māori people he studied, and recognised them as subjects and not objects of their history. The article argues that Cowan, the early oral historian who connected "places, people and memories" and captured Maniapoto voices speaking in their cultural present, has enriched our shared understanding of the tribe's past and traditions. The author, a Ngāti Maniapoto half-caste from Kihikihi, illustrates Cowan's contribution by locating his own personal journey of historical curiosity about his Maniapoto-Pākehā identity in the life and works of James Cowan.
\end{abstract}

The day before the symposium Cultural Go-Between, Colonial Man: New Perspectives on James Cowan, ${ }^{2}$ I was fortunate enough to preview the Alexander Turnbull Library's exhibition Borderland: The World of James Cowan, curated by Ariana Tikao. On entering the gallery space, I was immediately confronted by a larger-than-life image of an elderly James Cowan, or as Māori knew him, Hemi Kāwana or Te Kāwana. My immediate reaction was to greet this man: "E, tēnā koe Hēmi Kāwana." That moment inspired a personal reflection on how my journey of historical curiosity with regards to my Māori-Pākehā identity had intersected with, and been edified by, the life and works of James Cowan.

Like Cowan, my identity is located very much around the Kihikihi-Waipa district. I have origins intrinsically linked to the pioneering days of conflict, confiscation, and Pākehā settlement of the Waikato and the frontier border along the Pūniu River. Amid this, I have a genealogy that traces back to Hoturoa, captain of the Tainui waka; Maniapoto, the eponymous ancestor of my tribe; and a myriad other antecedents with histories which traversed the surrounding landscape for more than several hundred years prior to the coming of the European. I smiled when I read Alex Calder's remarks on Cowan in his introduction to the third edition of Tales of the Māori Bush. ${ }^{3}$ He said, "When James Cowan looked across farmland and up into the hills, he saw giant figures in the sky. The shades of bushmen following old forest trails might cross a newly gravelled road or Māori warriors stamp a misty haka from battlefields such as Orakau..." I myself am known to enjoy the same sort of imaginings when I travel "home" to the King Country and the Waikato.

What follows, then, is my attempt to provide $a$ (and not the) Ngāti Maniapoto perspective on James Cowan, interspersed with some personal family historical reflections from a half-caste. I seek to provide a particular Ngāti Maniapoto/Māori-centric view of Cowan's work, and something of a Māori methodological assessment of his approach to the collection and [re]presentation of Māori history and traditions. For me, this means the extent to which James Cowan empathised, identified with, and participated in the lives of the Māori people he was studying in order to understand their history and their cultural and social worlds - from their perspective. Furthermore, it requires some consideration of the extent to which Cowan centred Māori as subjects, rather than as objects, and thus made visible Māori 
agency; that is, consideration of whether he viewed and presented Māori as "agents, actors, and participants rather than as marginals on the periphery" of their colonial experience.

My friend and colleague Robert Joseph and I had recently led Ngāti Maniapoto's major oral and traditional history project to support the tribe's numerous claimants in the Waitangi Tribunal's Te Rohe Pōtae Inquiry. ${ }^{6}$ We both have whakapapa ties to Ngāti Maniapoto, and our methodological approach to this project was deliberately Maniapoto-centric. We sought historical accounts and explanations of traditions from Ngāti Maniapoto's viewpoint, drawing on Maniapoto informants and Maniapoto scholars, and a voluminous amount of unpublished and published kōrero or "native voice" in letters, newspapers, manuscripts, Native Land Court minute books, waiata, carvings, and more recent audio and visual recordings. We focused on Ngâti Maniapoto as the cultural centre for the study of Maniapoto oral and traditional history and we privileged those Maniapoto perspectives in our presentation of that research. Our overarching objective was to make visible Ngāti Maniapoto agency in this study of the tribe's past, and to highlight the strategies and tactics our tūpuna or predecessors employed as they negotiated and mediated the colonial structures and ideologies of the encroaching European settler. ${ }^{7}$ For us, the "native voice" offered the important perspective of the colonised about his/her colonial reality, an antidote to Pākehā historical perspectives.

In adopting such a position we were not seeking to dismiss nor diminish European culturally constructed narratives about Māori-Pākehā history of Te Nehenehenui, or what Pākehā (and later Māori themselves) came to call the King Country. Narratives such as these present the necessary Eurocentric perspective on events and encounters that unfolded, allowing us to consider the colonial structures, polices, and practices that European settlers contrived for colonising and subjugating the local Māori/indigenous population. ${ }^{8}$ The difficulty with Eurocentrism is that it relegates all other ways of thinking to the periphery. It merely sees reality in a single perspective and settles on Eurocentrism as the only determinant of true meaning and knowledge. ${ }^{9}$ It does not allow for multiple centres of seeing the world, all uniquely valuable in themselves, nor does it support multiple knowledge systems which are free of a hierarchy of truth.

James Cowan saw his work as a further contribution to the "great work of Māori research done in the past and still being done." ${ }^{10}$ He cites the likes of Percy Smith, Colonel W. E. Gudgeon, Elsdon Best, Edward Treagar, and Rev T. Hammond. The published works of these early Pākehā ethnographers have been the subject of criticism in recent years, particularly by proponents of Kaupapa Māori theory which challenges dominant Pākehā notions of theory and research and provides Māori "counter-hegemonic practice and understandings" informed by Māori philosophical underpinnings defined and controlled by Māori. ${ }^{11}$ Kaupapa Māori theory views those ethnographers as being imbued with the Eurocentric and racist assumptions which admittedly were for a long time a rarely-challenged characteristic of much popular writing about Māori by Pākehā. ${ }^{12}$

Huia Jahnke and Julia Taiapa have described these early Pākehā ethnographers as "cultural philanthropists," intent on recording for posterity the last vestiges of the Māori race. ${ }^{13}$ Linda Smith notes that they were driven by "the need to collect volumes of material ... to be recorded as rapidly as possible before it became polluted or lost." ${ }^{\prime 14}$ Russell Bishop argues that they "misrepresented, that is, simplified/conglomerated and commodified, Māori knowledge for 'consumption' by the colonisers." ${ }^{15}$ He concludes that their works consequently denied the authenticity of Māori experiences and voice.

The historian Chris Hilliard argues that most of James Cowan's contemporaries treated New Zealand history as a "history of European endeavour," consigning Māori to roles as "assistants, impediments, or "environmental factors." 16 Hilliard also contends, however, that Cowan's writings about Māori-Pākehā frontier stories differ "sharply from other contemporary or earlier Pākehā histories of New Zealand."17 Speaking of Cowan's writings, 
he asserts, "Māori did enter the narrative as forces in their own right... [T] some extent he recognised Māori agency, autonomy and dynamism."18

Therefore, despite our Maniapoto-centric positioning in the oral and traditional history project mentioned above, our review of the literature singled out James Cowan as a Pākehā commentator and scholar of Ngāti Maniapoto history and traditions whose works we needed to consult. This was largely because of his approach to the collection and [re]presentation of mātauranga Maniapoto, or Maniapoto knowledge. What we concluded for ourselves, from his publications as well as his papers and notes held in the Alexander Turnbull Library, was that Cowan demonstrated a discernible empathy for Māori. He sourced and interpreted data within a largely sound Māori cultural framework. He left a rich source of research material in the Māori language with attribution to his informants. He centred Ngāti Maniapoto as actors and subjects of their colonial experience. Further, and perhaps most importantly, through the use of lengthy quotations, he gave them voice. The editor of the Māori newspaper Te Toa Takitini seemingly shared our opinion of Cowan. In recommending his works to Māori, he remarked:

He tino tohunga a Te Kawana mo te tuhituhi pukapuka, he pai tana whakatakoto korero.... He tangata mohio ki te iwi Maori, mohio hoki ki te reo Maori.... Koinei nga tauira pukapuka e tika ana kia tangohia e nga Maori mohio ki te korero pukapuka i te reo Ingarihi. ${ }^{19}$ (James Cowan is a very skilled writer of books and good at telling stories.... He is a person knowledgeable of the Māori people, and knows also how to speak Māori... These are the sorts of books that knowledgeable Māori should read in English.) ${ }^{20}$

Of his book The Old Frontier, the editor approvingly wrote: "Kia ora e hoa e Te Kawana, mo tenei taonga whakamiharo, kua oti nei i a koe te whakairo, hei taonga tuku iho ki nga whakapaparanga e haere mai nei i muri i a tatou." 21 (Thank you my friend, Mr Cowan, for this splendid gift which you have completed [carved] as a treasure to be handed down to the generations to come after us.)

One such appeal to Māori was that Cowan often left us with graphic descriptions of tupuna, invaluable in the absence of a photograph. For example, Hopa Te Rangianini is a forebear of mine whom I had originally read about in Native Land Court minutes. How pleasing it was to read the following description by Cowan:

There was a singular attraction, too, about Hopa ... He was a man of short, compact frame, with an uncommonly massive head. His brow, high and broad, denoted intellect; his expression was a mingling of sternness and shrewdness. Every inch of that strong, hard old face was deeply incised and black-pigmented in the tattooer's best art; it was literally a carved head, trenched in the heroic manner of old. From chin and neck to his ears and the roots of his grey hair the old warrior was moko'd ... 22

Cowan pays tribute to Te Rangianini's wisdom and knowledge of mātauranga Māori, or what he describes as "esoteric lore" 23 (my emphasis).

Hilliard notes that Cowan's texts are strewn with racist terms and phrases. ${ }^{24}$ This is a question that must be addressed. Cowan writes, for example, of "the days of pure savagedom and of New Zealand's stone age." 25 To be fair to Hēmi Kawana, he was a product of his time, reflecting language that was current and popular for the period. Based on his works and papers, I suspect Cowan had more respect for Māori knowledge than seeing it merely as folklore. We should be wary of being too culturally defensive, as this can prevent us from reading beyond the wording to reach the substance.

David Colquhoun, in his biographical essay on James Cowan, states that while his works contain implicit assumptions about the fated decline of Māori in the face of colonisation

Journal of New Zealand Studies NS19 (2015), 5-15 
"he always held contemporary Māori in higher regard than did writers such as Elsdon Best."26 Writing in his preface to The Maoris of New Zealand, Cowan comments:

Those who really know the Maori ... cannot but have a liking for the race. Those who, like the writer, have seen the Maori at his best and worst, have a lively sympathy with his aspirations and a hope that he will regain his ancient vigour and vitality. ${ }^{27}$

Cowan did have a tendency to romanticise and lament the age of the dying chiefs, "the passing away of an old Maoridom like a tale that is told, and the enthroning of the white man with his cities and railroads, his steamers and telegraphs." ${ }^{28}$ Cowan himself was something of a cultural philanthropist. On the one hand, he was motivated by a quest to promote mutual understanding and reconciliation between Māori and Pākehā ${ }^{29}$ (as perhaps were his Māori informants) and on the other, by a desire to capture how things were in the past and the changes that took place before such elders disappeared and "before those with personal experience of them finally passed away." ${ }^{30}$ Alex Calder notes that Cowan wrote as if mana was a thing of the past: "His dignified and straight-backed kaumatua seem the last of their kind." ${ }^{11}$ As another example, writing of the prominent Ngāti Maniapoto chief, Hauauru, Cowan remarks he was:

Decidedly a more interesting type, that blanketed tattoo-spiralled old warrior, than the present generation of Maori rangatira, who as often as not wears tailor-made clothes of the latest pattern, has a piano and a graphophone in his European-built house, is proud of his break of billiards, and whirls to the races in a motor-car. ${ }^{32}$

Hauauru passed away in 1890, as did many of his Ngāti Maniapoto contemporaries during that decade: Rewi Maniapoto, Wahanui, and Taonui Hikaka to name a few.

To some extent, Cowan was reflecting a sentiment shared by Ngāti Maniapoto itself. A synopsis of Ngāti Maniapoto's history was attached to a covenant published in 1904, the Kawenata o Maniapoto (the Covenant of Maniapoto). The document observed: "No nga ra i a Mahuta, ka ngaro haere nga kaumatua whaimana o Ngati Maniapoto ki te matemate."33 (During the time of Mahuta, the elders who possessed mana began to disappear).

Notably, the tribe had not surrendered to the fatalistic perception of Māori as a dying race. The covenant aspired to unite and consolidate the tribe to regain what Cowan would describe as its "ancient vigour and vitality," the basis of which was to be their Māoritanga or Māori cultural foundations. ${ }^{34}$ By 1930 Cowan himself had acknowledged the resilience of Ngāti Maniapoto and other Māori tribes:

The Maori himself has given reply to these confident prophecies of his melancholy fate by declining to lie down and die... The Maori, in short, stands on his feet once more.... [T] here must be in the Maori a strong racial quality of physical and spiritual resilience, a power to rise superior to hostile natural forces. ${ }^{35}$

Hilliard notes that over the years Cowan had developed enough familiarity with and respect for Māori people that "large numbers of Māori came to trust him enough to share their stories with him." "36 This is evident, for Ngāti Maniapoto at least, from the large volume of stories that Cowan collected from our kaumatua or elders, many of whom he got to know intimately.

James Cowan's studies of Māori history and traditions favoured Māori oral testimony, ${ }^{37}$ which, given the infancy of Māori written literature, was the major source of the Māori perspective. In a preface to his collection Hero Stories of New Zealand, he wrote: "One cannot learn or write history exclusively from written documents... The generals and colonels did not know the war from the Māori side.... The officials did not know the frontier." ${ }^{38}$ Cowan wrote of his "field research" and the importance of locating himself among his Māori research 
participants whom he in fact described as his "tutors," rather than mere informants. ${ }^{39} \mathrm{He}$ commented: "I have spent years in gathering the real story on the spot ... Many days with old fighters, of both races." 40

A good example of the trust that James Cowan shared with Ngāti Maniapoto was his collection of the esoteric genealogy, commencing with Io and tracing the lines of descent of Maniapoto, the ancestor, from Te Marama (light) and Te Pō (darkness), sourced from the whakapapa records of the great Ngāti Maniapoto chief, Wahanui himself. This whakapapa appears unpaginated and unaltered in the Journal of the Polynesian Society, submitted by James Cowan with attribution to Wahanui. ${ }^{41}$ It is questionable, though, whether Wahanui himself, now departed, would have agreed with its publishing in this form. Some Māori were happy to have such knowledge published, but others were strongly opposed. ${ }^{42}$

Two Ngāti Maniapoto tutors in particular were Te Huia Raureti from Mangatoatoa on the Pūniu River and Poupatate of Te Kopua, a settlement at the base of the mountain Kakepuku. ${ }^{43}$ They were both veterans of Ōrākau. Cowan remarked:

Moving it was to listen to the two old comrades Te Huia Raureti and the blind man Pou-Pataté, the last of the defenders of Orakau, sitting side by side on the matted floor of the Puniu-side home, chanting together the old songs of war, now and again breaking off to explain the significance of the stirring lines they repeated. ${ }^{44}$

Cowan's ability to converse with local Māori in their language and his promotion of reminiscing as the major method of collecting histories would have held him in good stead with his elderly Ngāti Maniapoto informants. ${ }^{45}$ The act of reminiscing or recalling old associations or encounters is a favourite technique of the Māori to illustrate past connections in developing and maintaining social and political relationships to both land and people.

Cowan generally stayed faithful to his Ngāti Maniapoto collaborators, whose names and voices found their way into his numerous publications, rather than allowing "informants and the rest of their knowledge to lie buried in manuscripts and archives," a criticism that Linda Smith has levied at his contemporary Elsdon Best. ${ }^{46} \mathrm{He}$ exhibited research processes and ethical approaches that would be expected today of any good kaupapa Māori researcher. He sought out, among others, Raureti Te Huia of Ngāti Paretekawa (Mangatoatoa, Pūniu) to collaborate and assist him (hei hoa) in his collection of local Ngāti Maniapoto oral history and traditions. ${ }^{47}$ One such narrative collected was that of the kuia (old woman), NgārongoHerehere Rangitawa of Kāwhia. ${ }^{48}$ A translation of that kōrero or oral text appears in Cowan's The Maori of Yesterday under the chapter heading, "Kawhia. A Picture of the Past." ${ }^{49}$ It is attributed to his "Ngāti Maniapoto friend," Ngarongo-Herehere with a "bonus" accompanying description of this aged kuia. A comparison of the interview notes and the published material reveals a faithful translation, despite Elsdon Best's questionable claim that Cowan possessed a "very ordinary knowledge of the Māori tongue." 50

If there is one disappointment in Cowan though, it is that Cowan rarely published the reo Māori narratives that he collected, even in a bilingual format. His wider audience, of course, was English speaking. Nevertheless, we are fortunate that we do have the opportunity to uncover these te reo Māori narratives in his unpublished notes and papers, and to reclaim and republish them for ourselves as Ngāti Maniapoto. I believe Cowan would be supportive of such an endeavour.

Part of James Cowan's credibility with his Ngāti Maniapoto "tutors" would have also been his association from childhood with the Kihikihi-Waipa district and in particular, the locality of Ōrākau, once known for its Māori wheat fields and orchards. Indeed, I myself was first attracted to James Cowan because of my own deep family associations with Kihikihi Township and the surrounding district, the subject of much of his writing. In the historical construction of Māori and Pākehā identities, of native and settler, I find myself situated as both.

Journal of New Zealand Studies NS19 (2015), 5-15 
Thus when I discuss the Waikato Wars during the 1860s, I can and do speak of ancestors on both sides of the battle line. Among them is Mere Te Rongo-pāmaomao who went with Ngāti Kinohaku to expel the government agent, Gorst and was at Rangiaowhia when it was invaded. Carrying her baby she hid in the bush hearing the shouts of the soldiers, "Maoris in the bush! Shoot em! Shoot em!" 51 According to one family story, she had a child to William Gilbert Mair, famous for calling on the defenders of Örākau to surrender and the first judge of the Native Land Court when it commenced sittings in the King Country. That child was my great, great, great-grandfather. On my Pākehā (father's) side I make mention of Private Richard Double (a.k.a. Theodore John Meredith), who served in the Second Waikato Militia. ${ }^{52}$ T. J. Meredith went on to join the Armed Constabulary, whose duties included patrolling the Punniu River border, across which were the places Te Waiaruhe and Whenuahou at Tokanui. These were settlements of my hapu or subtribe, Ngāti Kaputuhi. Ngāti Kaputuhi claims Rewi Maniapoto among its forebears through his mother's genealogy.

I have vivid childhood memories of playing around Rewi Maniapoto's monument across the road from the Star Tavern; passing the Öräkau monument on the way to the river for a swim; visiting my Pākehā uncle's farm at Rangiaowhia alongside the big blue church; picking watercress with my grandfather at his secret patch at Hairini; the old house across the road from my grandparents' which apparently belonged to someone called Major Jackson; my Pākehā grandmother pointing out on the lengthy Paterangi road where she grew up; living on Grey $\mathrm{St}$ near other roads with names such as Ballance, Sheehan, and Whitmore; crossing the Pūniu River and noticing the sign on the bridge, "Northern King Country"; and frequently gazing at the mountains called Pirongia and Kakepuku and the little hill known as Kawa. It would be later that my interest in our local Māori-Pākehā history and a desire to understand my "halfcaste" identity led me to a book by James Cowan called The Old Frontier: Te Awamutu, The Story of the Waipa Valley. ${ }^{53}$ Suffice it to say, reading this work and other subsequent writing by James Cowan was an historical enlightenment as to the significance of some of these names and "familiar home landscapes." 54

Cowan came to understand the significance of places and landmarks that were affectionately conceived as ancestors and as important geographical reference points for Māori identity. He once wrote of Kakepuku that it "seemed to boyhood's eyes an enchanted mountain, with infinite suggestion of mystery and adventure." ${ }^{55}$ He hoped one day the Pākehā would come to look upon the mountain "with something of the affection which the native feels for "my ancestor the Mountain." ${ }^{56} \mathrm{He}$ often cited the following chant:

Ko whea, ko whea

Ko whea tera maunga

E tu mai ra ra.

(What tall ye yonder mountain Standing above us there?) ...

Tis Kakepuku,

Tis Pirongia!

Ah, draw close to me,

Draw close to me,

That I may embrace you.

That I may hold thee to my breast!

$\mathrm{A}-\mathrm{a}-\mathrm{ah} !^{57}$

I recall reading James Cowan's Journal of the Polynesian Society article on mountains and fairies and the section on "The Patu-Paiarehe of Pirongia and Kakepuku." 58 This captures the story behind that waiata patupaiarehe or fairy song, "Kaore te Rangi nei." This waiata tells the love story of Whanawhana and Rangipouri, the chief of the fairy people on the mountain Pirongia, a dominant geographical feature of the Waipa landscape. Subsequent to reading this 
article, I consulted the late Tui Adams about the waiata. Tui was a renowned Ngāti Maniapoto kaumatua steeped in the knowledge systems of Tainui. Tui's remarks to me about the patupaiarehe of Pirongia was so aligned to James Cowan's account that I was sure that this elder must have read the aforementioned journal article, but Tui had not read the article. Tui's information had been passed on to him by word of mouth from his mentor Henare Tuwhangai, another well-known tribal repository of Tainui knowledge. However, Tui recognised James Cowan's informant on the patupaiarehe of Pirongia as one who imparted much knowledge to Henare Tuwhangai about the surrounding Waipa district. This to me was testament both to James Cowan's accuracy in his recording of Māori history and tradition, and the reliability of oral tradition amongst the Waikato-Maniapoto peoples.

In a sense, Cowan possessed a sort of whakapapa or an affinity to the Waipa area. He claimed he knew no other area with a stronger "landscape interest conjoined to the traditional and historic":

Beauty of physical configuration, fertility of soil, poetic Maori folklore, memories of the heroic pioneer days, tales of sadness and glory of the war years - all these elements combine to invest the border line of the Waipa and the Rohepotae with a singular value, above all to those who have had the fortune to be reared on this well-favoured land. ${ }^{59}$

Cowan grew up at Ōrākau from 1870 onwards, not too distant from the aukati, the frontier between Pākehā and the northern reaches of Ngāti Maniapoto territory. This was merely six years after Ōrākau was the scene of that famous battle between a force of 300 Māori led by Rewi Manga Maniapoto against an overwhelming force comprising 1,700 British and colonial soldiers. His father, William Cowan, acquired the land at Ōrākau to farm, a share of the spoils of the confiscated territory from the Waikato War campaign. The family farm included part of the actual battlefield of Ōākau. Cowan recalled how he and other children would find bullets in the ground turned up by the plough, and that they explored the scarred old peach trees with their pocket knives for bits of lead. ${ }^{60}$ In his publication with Sir Māui Pōmare, Legends of the Māori, Cowan recalled playing as a child in the orchard at Ōrākau when a group of Māori horseback riders appeared:

A group of mounted Maori, most of them old men with tattoo-carved faces halted on the gentle mound of Rangataua, at Orakau, where the wagon road ran, and gazed about them over the green farm lands that sloped easily to the bush and the raupo swamps. One of them pointed to this place and that; he was reconstructing for his companions an episode of the past. As I watched them over the hedge from the peach-grove I heard one of the grim old warriors begin a wavering chant, a song that rose and fell in slow cadences of sorrow. Presently the others joined him and they chanted all together, and tears flowed down their chisel-trenched, bluescrolled cheeks as they sang. I did not know then what they chanted, but I knew this much, that they were mourning for Orakau. ${ }^{61}$

In my opinion, Cowan does well here to capture in a Māori sense the emotion and the solemnity of this moment and place. Cowan, the literary raconteur, and his approach to putting "places, people and memories" 62 together, is commensurate with the manner in which Ngāti Maniapoto have preferred to recall their history.

Cowan explains that within a few years of experiencing that moment at Ōrākau, he began to collect local history and learn the local Māori language. Gregory Wood observes that: "All alone in the peach orchard, Cowan eavesdropped on a poignant ceremony, a tangi, and observed a grief so deep that he determined to learn the Māori language and start gathering their folklore." ${ }^{\text {"If }}$ If this is true, then the origin of Cowan's interest in things Māori has a strong 
and poignant wairua Māori, or Māori spiritual basis, even if Cowan didn't recognise it as such. Māori were more than an academic interest for Cowan.

The year 2014 marked the $150^{\text {th }}$ commemorations of the Battle of Ōrākau. Cowan's writings did much to uphold the Battle of Ōrākau as an iconic event in New Zealand's colonial history. Writing about the battle, Cowan pronounced:

No heroic episode in New Zealand's history surpasses in fame the siege and defence of Orakau $\mathrm{Pa}$, where the Kingite Maoris made their last stand in the Waikato War.... The chief figure in the defence, Rewi Maniapoto, was the most vigorous and uncompromising of the Maori Nationalist leaders throughout the war. He and his near kinsmen ... were known to the writer from his early years on the sacred soil of Orakau battlefield and the King Country frontier. ${ }^{64}$

As part of the commemorations, Robert Joseph and I prepared a small publication collecting the known Māori accounts of what Cowan described as a "Māori Thermopylae."65 Significantly, James Cowan collected most of these "native accounts," some of which we were able to access in notebook form and in Māori, and others in published form. These Māori oral narratives formed the basis of his chapter about the Battle of Örākau in his seminal two-volume work on the New Zealand Wars published in 1922 and 1923 respectively. ${ }^{66}$ This was at the time the "official history" of those wars. Most significant, perhaps, is that Cowan's "official history" encompassed several Māori versions of the events of the Battle of Ōrākau and other conflicts. Cowan recognised that a history of New Zealand was inadequate when only Pākehā perspectives were utilised. Our collective memory of Örākau arguably owes much to James Cowan. He placed an extraordinary body of evidence on the public record from both sides. Indeed, our little contribution to the $150^{\text {th }}$ commemorations would have been much the poorer had not Cowan collected those Māori accounts which we were able to reclaim and republish.

\section{Concluding Remarks}

Generally speaking then (and quite aside from the value of his work to identity formation for a "half-caste" from the Kihikihi region), from a Ngāti Maniapoto perspective, I would argue that the tribe was fortunate to have James Cowan active as a student and researcher of our mātauranga, our tribal knowledge and historical narratives. Cowan exhibited an empathy and respect for the Māori worldview born out of childhood experiences of people and place. He was not a trained academic. He operated in the worlds of journalism, literature, and most importantly, oral history. His capturing on record those Maniapoto voices and intellectuals who were part of key moments of our colonial experience has proved invaluable.

In sharing our histories among ourselves and with others, such as the Waitangi Tribunal, we have been able to excavate, recover and reclaim those voices of our tupuna speaking in their cultural present, critique their own interpretive and contextual biases, and (to a significant degree) inform modern debates with a certain level of "authenticity." This "Maniapoto/Native Intellectual History" ${ }^{\circ 7}$ has allowed us to listen and attend to the native voice, ${ }^{68}$ to debate and correct inaccuracies and assumptions which have developed with the passage of time, and extend our shared understandings of particular concepts and histories.

Simply put, without James Cowan and his "Maniapoto tutors," we would know much less of our tribal past. Nō reira, Hèmi Kawana, tènā rawa atu koe. E moe koe i tōu moenga roa.

\footnotetext{
${ }^{1}$ I wish to thank my partner Leah Gifford for her helpful comments on an earlier draft of this article. I would also like to thank the journal's anonymous readers for their considered feedback.
} 
${ }^{2}$ Hosted by the Alexander Turnbull Library and the Centre for Research on Colonial Culture, University of Otago, National Library of New Zealand, Wellington, 21 February 2015. I also wish to thank Annabel Cooper and Ariana Tikao for the invitation to be part of this symposium. This article is based on an oral presentation I gave at the symposium. My friend and colleague, Dr Robert Joseph and I were asked by the conveners to give an "iwi perspective" of this well-known author of New Zealand colonial history and Māori ethnography. As students of Māori history, social, and cultural life, and with a recent focus on Ngāti Maniapoto, we were very familiar with the works of Hēmi Kāwana and his romance of the Rohe Pōtae, the King Country. Unfortunately, Robert was unable to attend the symposium, having been invited to speak at the $150^{\text {th }}$ anniversary of what Cowan described as the "Invasion of Rangiaowhia," one of several commemorative events of the Waikato Wars. I was thus left to give a solo performance.

3 (1934; rpt. Auckland: Reed, 2006), 7.

${ }^{4}$ Ibid.

${ }^{5}$ See Molefi Kete Assante's entry on Afrocentricity in Vincent N. Parillo's Encyclopedia of Social Problems (California, Sage, 2008), 34. I have found the work of Dr. Molefi Kete Asante and his "Afrocentricity" paradigm to be very useful in thinking about Māori agency and subject place in the colonial experience. Through Afrocentricity, Assante seeks to place Africans at the centre of their own historical narratives but importantly recognises that it is only one of a multiplicity centres. It does not deny others their centre. See also Molefi Kete Assante, Afrocentricity: The Theory of Social Change (Chicago, African American Images, 2003); Moelfi Kete Assante, The Afrocentric Idea (Philadelphia: Temple University Press, 1998).

${ }^{6}$ See Paul Meredith, Rewi Nankivell and Robert Joseph, Ngāti Maniapoto Mana Tangata, Scoping Report for a Ngāti Maniapoto Oral and Traditional History Project, research report commissioned by the Crown Forestry Rental Trust for the claimants, 2010, Wai 898 A114, Te Rohe Pōtae inquiry. See also Miria Tauariki, Te Ingo Ngaia, Tom Roa, Rovina Maniapoto-Anderson, Anthony Barrett, Tutahanga Douglas, Robert Joseph, Paul Meredith, and Heni Matua Wessels, Report for Ngāti Maniapoto Claimants and the Waitangi Tribunal, research report commissioned by the Crown Forestry Rental Trust for the claimants, 2013, Wai 898 A110, Te Rohe Pōtae inquiry.

${ }^{7}$ See Stephen Silliman, "Agency, Practical Politics and the Archaeology of Culture Contact," Journal of Anthropological Archaeology 2 (2001): 190-209.

${ }^{8}$ Kent G. Liftfoot, Indians, Missionaries, and Merchants: The Legacy of Colonial Encounters on the California Frontier (California, University of California Press, 2006).

${ }^{9}$ Ella Shohat and Robert Stam, Unthinking Eurocentrism: Multiculturalism and the Media (New York: Routledge, 1994).

${ }^{10}$ James Cowan, The Maoris of New Zealand (Christchurch: Whitcombe \& Tombs, 1910).

${ }^{11}$ Graham H. Smith, The Development of Kaupapa Maori Theory and Praxis, unpublished Doctoral Thesis, School of Education (University of Auckland, 1997), 455. For further discussion on Kaupapa Māori Theory, see Linda Tuhiwai Smith, Decolonising Methodologies: Research and Indigenous Peoples (London, Zed Books; Dunedin, Otago Press, 1999); Leonie Pihama, "Kaupapa Māori theory: Asserting indigenous theories of change," in Sovereignty Matters: Locations of Contestation and Possibility in Indigenous Struggles for Self-Determination, ed. J. Barker (Lincoln, NE: University of Nebraska Press, 2005); Rangimarie Mahuika, "Kaupapa Māori theory is critical and anti-colonial," MAI Review 3 (2008): article 4, retrieved online from http://www.review.mai.ac.nz/index.php/MR/article/viewFile/153/180; Leonie Pihama, "Kaupapa Māori Theory: Transforming Theory in Aotearoa," in Kōrero: A Journal of Māori Studies 9, no. 2 (2010): 5-14.

${ }^{12}$ David V. Williams, Mātauranga Māori and Taonga (Wellington, Waitangi Tribunal, 1997), 110.

${ }^{13}$ Huia Jahnke and Julia Taiapa, "Maori Research," in Social Science Research in New Zealand, ed. Carl Davidson and Martin Tolich (Auckland: Longman, 1999), 40.

${ }^{14}$ Decolonising Methodologies, 83-85.

${ }^{15}$ Collaborative Research Stories: Whakawhanaungatanga (Palmerston North: Dunmore, 1996), 14.

${ }^{16}$ Hilliard, "James Cowan and the Frontiers of New Zealand History," New Zealand Journal of History 31, no. 2 (1997): 225.

${ }^{17}$ Ibid.

Journal of New Zealand Studies NS19 (2015), 5-15 
${ }^{18}$ Ibid.

19 "The Old Frontier: He Pukapuka Hou," in Te Toa Takitini 31 (8 February 1924): 13.

${ }^{20}$ Translations in this article are by the author.

${ }^{21}$ Te Toa Takitini 31: 13.

${ }^{22}$ Sir Māui Pōmare and James Cowan, Legends of the Maori, Vol. 1 (New Zealand, Southern Reprints, 1987), 85. Online at http://nzetc.victoria.ac.nz/tm/scholarly/tei-Pom01Lege.html.

${ }^{23}$ Ibid, 86.

${ }^{24}$ Hilliard, "James Cowan and the Frontiers of New Zealand History," 223.

${ }^{25}$ Cowan, The Maoris of New Zealand, 6.

${ }^{26}$ David Colquhoun, "Cowan, James," Dictionary of New Zealand Biography. Te Ara - the

Encyclopedia of New Zealand, updated 7-Jun-2013

http://www.teara.govt.nz/en/biographies/3c36/cowan-james

${ }^{27}$ Cowan, The Maoris of New Zealand, xii.

28 "Patara, The Scribe," Star, 18 February 1902, 4.

${ }^{29}$ See Gregory Wood, "Revisiting James Cowan: A Reassessment of The New Zealand Wars (192223)," MPhil thesis (Massey University, Auckland, 2010); see also Peter Fraser's foreword in Tales of the Maori Border (Wellington, Reed, 1944).

${ }^{30}$ See Alex Calder's introduction in James Cowan, Tales of the Maori Bush, 8.

${ }^{31}$ Ibid, 10.

${ }^{32}$ Cowan, The Maoris of New Zealand, 7.

${ }^{33}$ Mahuta was the third Māori King, ruling from 1894 to 1912. See He Kura Rere in Pepene Eketone, H. Hemera Wahanui, H. M Hetete, H. T. Hetete, Moerua Natanahira and Hone Omipi, Ko te Kawenata o Ngāti Maniapoto me ona hapu maha (Te Nehenehenui, Ngāti Maniapoto, 1904).

${ }^{34}$ Eketone et al., Ko te Kawenata o Ngāti Maniapoto.

${ }^{35}$ James Cowan, The Maori of Yesterday and Today (Christchurch, Whitcombe and Tombs Limited, 1930), 2. Online at http://nzetc.victoria.ac.nz/tm/scholarly/tei-CowYest.html.

${ }^{36}$ Hilliard, "James Cowan and the Frontiers of New Zealand History," 223.

${ }^{37}$ Ibid, 219.

${ }^{38}$ James Cowan, Hero Stories of New Zealand (Wellington: Harry Tombs, 1935), x. Online at http://nzetc. victoria.ac.nz/tm/scholarly/tei-CowHero.html

${ }^{39}$ Ibid, xii.

${ }^{40}$ Ibid, $x$-xi.

${ }^{41}$ Vol. 14, 1905. The whakapapa also appears in Cowan's The Maori of Yesterday and Today, 52-55.

${ }^{42}$ See the comments of Hiki Makawa in Te Puke Ki Hikurangi, no. 1, vol. 5, 30 August 1902, 4.

${ }^{43}$ See "Death of a Maori Chief," New Zealand Herald, 11 June 1935, 11; and "Last of the Orakaus," Auckland Star, 8 August 1931, 10.

${ }^{44}$ Cowan, Hero Stories of New Zealand, xi.

${ }^{45}$ See Chris Hilliard, "James Cowan and the Frontiers of New Zealand History," in Island Stories:

The Writing of New Zealand History 1920-1940, MA thesis (Auckland University, 1997), 37, retrieved online from http://nzetc.victoria.ac.nz/tm/scholarly/tei-HilIsla-t1-body-d3.html.

${ }^{46}$ Smith, Decolonizing Methodologies, 85.

${ }^{47}$ See "Letter from Raureti Te Huia and papers relating to Orakau," in James Cowan Papers, Alexander Turnbull Library (ATL), MS-Papers-11310-142.

${ }^{48}$ See "Material in Maori from Raureti Te Huia," James Cowan Papers, ATL MS-Papers-0039-11.

${ }^{49}$ Cowan, The Maori of Yesterday and Today, 192.

${ }^{50}$ Colquhoun, "Cowan, James." Perhaps it was "ordinary" in that he grew up speaking the language and surrounded by it. So it might have been more of an everyday Reo, and perhaps he was not as skilful at interpreting the more formal types of language?

${ }^{51}$ Rora Paki-Titi, Rangimarie, (Wellington, Huia, 1998), 17.

${ }^{52}$ Peter Harman, Meredith: The story of a New Zealand Pioneering Family (Auckland: Peter Harman, 1982).

${ }^{53}$ (Te Awamutu, Waipa Post, 1922). Online at http://nzetc.victoria.ac.nz/tm/scholarly/teiCowOldF.html.

${ }^{54}$ Cowan, The Old Frontier, preface.

Journal of New Zealand Studies NS19 (2015), 5-15 
${ }^{55}$ James Cowan, “A Mountain of the Border," Auckland Star, 19 September 1914, 8.

${ }^{56}$ Ibid.

${ }^{57}$ Cowan, The Old Frontier, 8-9.

58 "The Patu-paiarehe. Notes on Maori Folk-tales of the Fairy People. Part II, by James Cowan," Journal of the Polynesian Society 30, no. 119 (1921): 142.

${ }^{59}$ Cowan, The Old Frontier, 7.

${ }^{60}$ See James Cowan's "Famous New Zealanders - No. 5 - Rewi Maniapoto - The Story of Orakau," The New Zealand Railways Magazine 8, no. 4 (August 1, 1933): 29; "Orakau," Auckland Star, 17 March 1914, 9.

${ }^{61}$ Pomare and Cowan, Legends of the Māori, xvii.

${ }^{62}$ Calder's introduction in James Cowan, Tales of the Maori Bush,

${ }^{63}$ Wood, Revisiting James Cowan, 28.

${ }^{64}$ Cowan, "Famous New Zealanders - No. 5 - Rewi Maniapoto", 25.

${ }^{65}$ Cowan, Hero Stories of New Zealand, 100. See Robert Joseph and Paul Meredith, The Battle of Orakau: Māori Veteran's Accounts (Te Kuiti, Ōrākau Heritage Society; Te Kuiti, Maniapoto Māori Trust Board, 2014).

${ }^{66}$ For what is probably the most detailed account of the Battle of Örākau, see James Cowan, The New Zealand Wars and the Pioneering Period (Wellington: Government Printer, 1922), 365-407.

${ }^{67}$ I am adapting a phrase here by American Indian Scholar Robert Warrior, who talks of "Native Intellectual History." See Robert Warrior, Tribal Secrets: Recovering American Indian Intellectual Traditions (Minneapolis: University of Minnesota Press, 1995).

${ }^{68}$ For a useful discussion about the value of attending to the "native voice," see Paul Meredith and Alice Te Punga Somerville, "Kia rongo mai ki taku whakaaro: The Native Voice in the Turnbull Library," The Turnbull Library Record 43 (2010/11): 96-105. 